\section{二, 三の血液相成よりみた鋠效果}

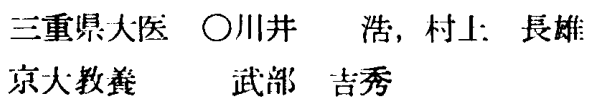

既報の如き特徽ある血液性:状を有寸る鍛練体質は，住 日 $10 \sim 15 \mathrm{~km}$ 程度走行 1 ケ月間継続では得られず， 日 本有数の大学ラグビー部員では認められたが，大学野球 部員では一般学生と殆んど変らず，老農夫で類似の状態 を発見したに過ぎなかつた．即ち，同じ鍛練にしてもか なり強力なるのを長期間に亘つて継続しない限り，特徵 ある鍛練体質は獲得できない様である，その原因究明の ため以下家鬼で実験を行なつた。即ち，Ad 連続投与に より全く類似の状態が招来されたことより，運動時作用 增大寸る交感神経又はその類似作用物質の一過性の影響 の碃重ねが，斯る体質形成に貢献する様である。しか し，運動により $\mathrm{ADH}$ 分泌及び副交感神释作用の增大 する時期があるが，下垂体後葉ェキス連絸投与では，途 中9〜14 日辺り迄は類似の血液性状を示したが，血獎蛋 白濃度の增大した点稍々異る様であり，Ach 連続投与 では, 赤血球数減少以外は殆儿ど血液性状に影響が現わ れなかつた，故に，之等は休質形成の主因とはなり得な
い様である. 又，赤血球数は女性が男性より少なく， 鍛練休質は女性の体質とかなり類似点があるが，去勢婎

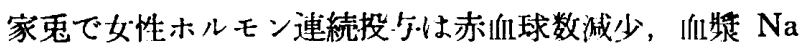
濃度士昇といら類似の状態を招来したがK濃度も上升し た点稍異る。一方，村」はは高度な身体毁練を伴う合宿綀 習早朝第二回尿，長旦つ強な運動後に見られる血厈陰性: 相突入期の尿中・血中及び家鬼で Ad 静注啳の尿中に 降圧物質である Kallikrein 様の ux 物質の発現增加を 見て㧍り，桝村は斯る時期の 5-HT (降圧物質)の関·与. を述べているが，Kallikrein 連続投与に上り薪明な赤 血球数減少，血漿 $\mathrm{Na}$ 濃度上昇等の $\mathrm{Ad}$ 投与に上る影 響と類似の招態が招来されたが，5-HT 投与では之等 血液性状の变化は軽度乃至軽無であつた．即ち，身体運 動によつて発動された強力な交感神経作用が，二次的に 拮抗的に作用する物質の様な降圧・蛋白尿発現物質の分 必を促進し，生体泟同化的・抑制的作用を及ぼし，之 の積重ねが鍛練体質形成の方向を取らせるのではないか とる考兄られる。笑際，ラットに Kallikrein, 5-HTを 投与すると、鍛練効果が抑制されることからもこのこと は首肯される。

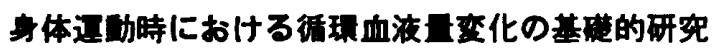

京都大学教養部 $\bigcirc$ 武 部 吉 秀 三重大学医学部 村 上 長 雄

既に著者及び川井，中田等によつて身体運動で招来さ れる種々の生理的機能変化のかなりの部分が運動時にお。 ける副腎随質ホルモンの分泌增加に基つく可能性がある ことについて報告されてきた，姑に家鬼で Adrenaline (Ad.) 静注の循環血液量の消長に及ぼす影響を検して強 力な運動によつて招来される循懪血液量の消長を推測す

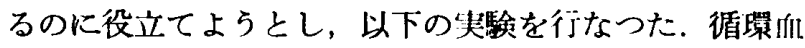
液量測定には Evans Blue 簡便法を朋い同一の家鬼で 2月 月上上間隔で行なつた（A）家鬼耳静脈より $0.3 \%$ E.B. 水溶液（E.B.S.） $0.3 \mathrm{ml}$ を注射し 4 分後に心臟值 接穿刺により血液 $1.5 \mathrm{ml}$ をとりこれを资料として安静 時循環少液量を求めた。（B）耳静脈より E.B.S. $0.3 \mathrm{ml}$, 1 万倍 Ad. 溶液 $1.0 \mathrm{ml}$ の混液を静注し 4 分後に心葴直 接穿刺に上り血夜资料を採取した。この循曙血液量測定 值は Ad. 静注に上り 血厈が著しく上昇している時期 のものを晛わするのとみてよい，(C) 耳静脈に1万倍 Ad. $1.0 \mathrm{ml}$ 静注 後 4 分月に E.B.S. $0.3 \mathrm{ml}$ 静汗しその 後 4 分日に心葴直接穿刺に上り和液资料を採取した，こ
の循環血液量測定値は Ad. 性:向压陰性相におけるるの を示すものとみてよい（D）取静注より1万倍 Ad. $1.0 \mathrm{ml}$ 静注後 8 分目に E.B.S. $0.3 \mathrm{ml}$ を静注しその後 4 分目に心臟直接䍓刺により血液资料をえた。この循環血 液量測定値は陰性相からの回復期におけるるのを示する のとみてよい，循環血夜量は（B）で若干犁り (C) で 顕著に減少し（D）でかなりの回復がみられた，即ち陰

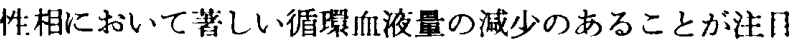
された，この基因は次の如し．（1）Ad. 静注後陰性相 を示す時期に家鬼耳·紐血管の扯張が浔められ，陰性相脱 却時その回復がみられること. Buffer Nerves 切断後 にはこれらの変化が起り難いことより血管運動神経反射 がかかる血管変化の原因となるであろう，纤管運動神絽 は静脈系の緊張にも関連し循瑾 Capacity を增大させ ることが循罢血浓量减少に関係があるものと考兄られ る.（2）家鬼で Ad. 静注後及び運動後における陰性相 で卹中 Catecholamine は安静時值の Level 以下には 落ちなかつた。故に末梢血管执張は从因性: Catechola-

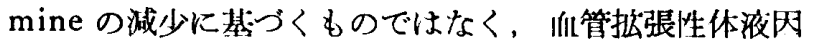
子の関与も考えられるが，神経系の影響が以上の上らた

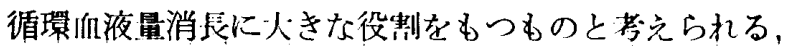

